\title{
Research on the Construction of the Quality Guarantee System of E-marketing Practice Teaching
}

\author{
Jun ZHAO \\ Wuhan Textile University, Wuhan, 430073, China \\ Email: 282762010@qq.com
}

Keywords: E-marketing; practice teaching; the quality guarantee system

\begin{abstract}
As a newly-emerging course with strong integration, e-marketing involves economics, management, network information technology and marketing. To better adapt to new situations and train high-quality e-commerce talents, it is very urgent to construct the quality guarantee system of e-marketing practice teaching. Thus, this paper firstly elaborates on the construction principles and practice module design of e-marketing practice teaching. And then, to better comply with the market requirements for talents, it presents the construction of quality guarantee system of e-marketing practice teaching by constructing the quality system of management, assessment and teaching conditions.
\end{abstract}

\section{Introduction}

As a newly-emerging marketing model based on the internet, e-marketing achieves marketing objectives by virtue of the interaction of digitalized information and online media. [1] Nowadays, it has become the most prevailing model among current enterprises especially small and medium enterprises. And as for the E-marketing curriculum, it is an interdiscipline and involves economics, management, network information technology and marketing. Students majoring in international trade, marketing and e-commerce are always required to take this course. This course is well-known for its strong practicalness. [2]In the teaching, it usually consists of theory teaching and practice teaching. [3] Nowadays, foreign colleges lay emphasis on the training of students' ability of practice, encourage students to keep balance between theoretical study and part-time job and inspire students to put theories into practice like creating websites for enterprises, running their own websites and online stores. [4] However, the curriculum of domestic e-marketing practice teaching nowadays are facing many problems including being inconsistent with enterprises' requirements, shortage of case sources, shortage of experienced teaching staff, shortage of professional training and so on.

\section{Significance of Constructing the Quality Guarantee System of E-marketing Practice Teaching}

On $29^{\text {th }}$ December, 2016, the Ministry of Commerce, the Cyberspace Administration of China and the National Development and Reform Commission jointly issued the document The Five-Year Development Plan of E-Commerce which explicitly defined 40 trillion Yuan in e-commerce transactions, 10 trillion Yuan in online retail sales and 50 million employers by 2020 as the future three development index. [5] It aims to realize the industrialization of the training of e-commerce talents through improving the information service market, enhancing the training of e-commerce talents and creating the personnel market for e-commerce talents. [6]Thus, to better comply with the new situation and train high-quality e-commerce talents, it is high time to establish the quality guarantee system of e-marketing practice teaching.

\section{Construction Principles and Training Module Design of E-marketing Practice Teaching}

\section{A. Construction Principles of E-marketing Practice Teaching}

a. Comprehensiveness

The system of e-marketing practice teaching should take students' majors, career prospects and needs to start up business into consideration. That means, when establishing this system, we should 
not only make the most of students' specialized knowledge and improve their ability of self-marketing, but also attach great importance to the cultivation of their abilities of job hunting and entrepreneurship and the training of professional innovative talents.

b. Systematicness

E-marketing practice teaching can improve students' abilities systemically through kinds of training items. [7]For instance, the process of marketing plan including investigation, analysis, planning, proposal writing, project defense, project evaluation and project revision can expectedly enhance their abilities of market insight, problems analysis and solution, proposal writing, organization and coordination. Besides, all projects are required to decide the practice time, tasks and objectives in line with the market and their majors so as to support their theoretical study.

c. Practicability

E-marketing practice teaching should be in accordance with the market. That means, it should be clear about the actual requirements for professional talents of enterprises. And then, in line with enterprises' actual jobs and objectives, it should increase students' attention to job requirements, improve their knowledge reserve and finally make them serve enterprises better by attracting them to take active part in it

d. Being Shared

E-marketing practice teaching should share information among students, teachers and cooperators since it can integrate kinds of social resources, teaching resources and practice teaching resources of many majors. Through the shared information, the market and students can understand each other better and teachers can improve their quality and ability theoretically and practically by cooperating with others.

e. Flexibility

E-marketing practice teaching should decide and adjust its contents, methods and objectives in line with different majors and requirements so as to thoroughly train students' abilities of both theoretical study and practice.

B. Training Module Design of E-marketing Practice Teaching

\begin{tabular}{|c|c|c|}
\hline $\begin{array}{l}\text { Training } \\
\text { modules }\end{array}$ & Training projects & Training content \\
\hline \multirow{3}{*}{$\begin{array}{l}\text { Opportunities of } \\
\text { online business }\end{array}$} & $\begin{array}{l}\text { Releasing business } \\
\text { information by } \\
\text { networking tools }\end{array}$ & $\begin{array}{l}\text {.Register and log in the BBS of e-marketing. } \\
\text {.Releasing business information on BBS. } \\
\text {.Releasing business information in the part of news }\end{array}$ \\
\hline & $\begin{array}{l}\text { Subscription and launch } \\
\text { of e-magazine }\end{array}$ & $\begin{array}{l}\text {.The foreground subscribe to e-magazine. } \\
\text {.The background launch e-magazine. }\end{array}$ \\
\hline & Simulations of online ads & $\begin{array}{l}\text { Releasing, managing and analyzing online ads by virtue of } \\
\text { the online advertisement system. } \\
\text {. Being able to releasing manual online text ads. }\end{array}$ \\
\hline \multirow{2}{*}{$\begin{array}{l}\text { Marketing } \\
\text { research }\end{array}$} & $\begin{array}{l}\text { Research of online } \\
\text { market }\end{array}$ & $\begin{array}{l}\text { Designing the research report. } \\
\text {. Writing the research report. }\end{array}$ \\
\hline & $\begin{array}{l}\text { Design of online } \\
\text { questionnaire }\end{array}$ & . Designing a questionnaire of users' satisfaction to products. \\
\hline \multirow{2}{*}{$\begin{array}{l}\text { E-mail } \\
\text { marketing }\end{array}$} & $\begin{array}{l}\text { Application and use of } \\
\text { e-mail }\end{array}$ & $\begin{array}{l}\text { Applying a free e-mail. } \\
\text {. Using e-mail and its address book. }\end{array}$ \\
\hline & Use of e-mail list & . Collecting customers’ information by e-mail list. \\
\hline \multirow{3}{*}{$\begin{array}{l}\text { Website } \\
\text { promotion }\end{array}$} & Domain application & $\begin{array}{l}\text { Knowing well how to apply domain. } \\
\text { Knowing the fee of domain application. }\end{array}$ \\
\hline & Hiring a virtual host & $\begin{array}{l}\text { Hiring a virtual host and choosing a suitable way. } \\
\text {. Checking the revised information after entering the virtual host. }\end{array}$ \\
\hline & Search engine(SE) & $\begin{array}{l}\text { The common process and notes of SE application. } \\
\text {. How to realize website promotion by SE }\end{array}$ \\
\hline \multirow[b]{2}{*}{$\begin{array}{l}\text { Website } \\
\text { marketing }\end{array}$} & $\begin{array}{l}\text { Major ways of online } \\
\text { service and FAQ }\end{array}$ & $\begin{array}{l}\text { Knowing the major ways of online service. } \\
\text {. FAQ. }\end{array}$ \\
\hline & $\begin{array}{l}\text { Professional evaluation of } \\
\text { enterprise's website }\end{array}$ & $\begin{array}{l}\text { Professional evaluation of website including brief } \\
\text { introduction, explanation of evaluation range, } \\
\text { conclusion(advantages and shortcomings). } \\
\text {. Proposing corresponding suggestions. }\end{array}$ \\
\hline
\end{tabular}




\section{Construction of the Quality Guarantee System of E-marketing Practice Teaching}

A.Constructing the Institution Guarantee System of E-marketing Practice Teaching Management

Scientific management system of e-marketing practice teaching is the basis of the guarantee system of e-marketing practice teaching. Institution guarantee system should adhere to the principle of law-based education and improve kinds of rules and regulations according to lots of aspects and factors of practice teaching quality. Besides, it should strictly regulate practice teaching activities so as to constantly improve the practice teaching quality. What's more, colleges should give priority to the construction of management system, system about training base outside college according to the general system of e-marketing practice teaching.

B. Constructing the Assessment Guarantee System of E-marketing Practice Teaching

To give full play to the guiding, promoting and stimulating function of assessment, we should construct the assessment index system of e-marketing practice teaching, regularly assess the e-marketing practice teaching based on the appraisal program and link together the assessment results with the immediate interests of individual teacher. The assessment is the core and motivation for operating the quality guarantee system of the e-marketing practice teaching. In order to effectively continue the assessment work for a long time, it is necessary to establish corresponding incentive mechanism, self-restricting mechanism and feedback mechanism. The main content of incentive mechanism covers the linking of assessment with the interests of the examined so as to maximally stimulate the initiative of the teaching staff and students. On one hand, the incentive mechanism can make the examined actively participate in the assessment by rewarding the good and fining the bad. On the other hand, it points out the existing problems matter-of-factly to raise their consciousness and initiative to improve the quality of practicing teaching. Besides, the incentive mechanism of assessment can also play the role of self-discipline for the teaching management department and form more practical program of the e-marketing practice teaching.

C. Constructing the Guarantee System of E-marketing Practice Teaching Conditions

a. University-enterprise Cooperation Promoting the Training Base Construction of E-marketing

High-quality training base of e-marketing meets the needs of practice teaching. The training base should attach great importance to its quality and quantity. That means, the quantity should be enough for training and practice and the quality should be up to standard.

b. University-enterprise Cooperation Acquiring a Strong Faculty Group of E-marketing

Universities and enterprises are supposed to jointly develop the faculty group by introducing enterprise senior managers and technicians, optimizing the group structure and acquiring a strong faculty group consisting of college professional teachers and enterprise experts. Besides, teachers should go deep into the front line of enterprises and take active part in e-marketing training and practice, which finally creates a win-win model of university-enterprise cooperation

c. University-enterprise Cooperation Constructing Resources Database of E-marketing

Universities and enterprises should make full use of those training bases inside and outside the college, jointly develop training textbooks, teaching video and software of e-marketing and constructing resources database of e-marketing teaching. The University-enterprise Cooperation makes sure the precision of textbooks because they are all based on enterprises' real work. All projects, tasks and cases in the textbooks come from real work in enterprises. It successfully realizes the practicalness, professionalization, practicability and pertinence of textbooks.

\section{Acknowledgement}

In this paper, the research was sponsored by This paper is one part of a college research project of Wuhan textile University.(Project No. 14133103) and the name of the project is University-enterprise Cooperation Constructing the Quality Guarantee System of College E-marketing Practice Teaching. 


\section{References}

[1] Li Xiangjian, Chen Xiaomeng. Research on the guarantee system of practice teaching[J]. Jiangsu College Education, 2008(6).

[2] Chen Ping,Chen Fei. University-enterprise cooperation Constructing the guarantee system of practice teaching[J].Vocational and Technical Education, 2010(8).

[3] Dong Jingjie. Suggestions for the construction of the guarantee system in higher vocational college[J]. Educational Exploration, 2010(9).

[4] Wang Yong. Research on the construction of the guarantee system in higher vocational college [J]. Chinese Vocational and Technical Education, 2007(8).

[5] High Impact Learning:strategies for leveraging business results from trainning. Brinkerhoff,O. Robert,Apking, Anne M. . 2001

[6] Education of the twenty-first century: New professionalism in lifelong learning, knowledge development and knowledge sharing $[\mathrm{J}]$. Tom J. Weert. Education and Information Technologies. 2006 (3)

[7]A study of international students' perspectives on cross-cultural adaptation[J] . Malcolm Lewthwaite. International Journal for the Advancement of Counselling . 1997 (2) 